\author{
RAYMOND RAMCHARITAR
}

\title{
GORDON ROHLEHR AND THE CULTURE INDUSTRY IN TRINIDAD
}

\section{INTRODUCTION: AN OVERVIEW OF THE TRINIDAD CULTURE INDUSTRY}

Trinidad \& Tobago ("Trinidad") markets itself as a center of "cultural" tourism, and a producer of the academic knowledge its culture generates. In this, the country is not unique in the Caribbean. Such an orientation of a cultural economy and its discourse has been described by historian Barry Higman as "heritage tourism," where history, historical narratives, and the satellite festivals and activities become cultural products for commercial purposes. As late as February 2011, the Department of Creative and Festival Arts of the University of the West Indies (UWI), St. Augustine, hosted a seminar which reiterated the institution's commitment to the "Carnival complex": an integration of the social, economic, and intellectual aspects of the Trinidad Carnival into the country's quotidian social and economic life. ${ }^{1}$

This project has been proceeded, led, and endorsed by academics, with a remarkable sanguinity regarding the social-political problematic of the "culture industry" - specifically the meaning of the phenomenon as described by Theodor Adorno and Max Horkheimer (1999), the Frankfurt School and similar cultural theorists - and its social implications and consequences. Neither does the project's de facto function as an adjunct to the "nationalist" project seem to attract the appropriate amount of critical attention (Ramcharitar 2008b).

Adorno's theorizing of the culture industry is denunciatory. He argues that "culture" (materialized and disseminated in films, durable goods, architecture, art, and popular music) is used by economic and political power groups to bring about "the stunting of the ... consumer's powers of imagination and spontaneity," to make them consumerist automata, docile and easily manipulated (Adorno 1991:35). In Trinidadian (and West Indian) academia, the very recent acknowledgment of Cultural Studies as a formal discipline,

1. Videos of the main talks (and others) can be found at: http://www.youtube.com/user/ TriniData.

New West Indian Guide / Nieuwe West-Indische Gids vol. 85 no. 3 \& 4 (2011):191-214 
and its open ideological orientation toward the Carnival complex, have not given much hope that Adorno's critique will gain much traction. ${ }^{2}$

This does not mean that the critical examination of society and culture has been absent from West Indian/Trinidadian intellectual discourse, or that it has all been reactionary. From J.J. Thomas in the nineteenth century, to C.L.R. James, Lloyd Best, and V.S. Naipaul in the twentieth and twentyfirst centuries, the practice has been an integral part of the intellectual and artistic narratives of the country and the region. Indeed, cultural criticism is an inevitable consequence of the colonizer-colonized relationship, where values, practices, and beliefs are hierarchized and economies of status are imposed on subject peoples by colonizers.

But in the present, Trinidad, like other West Indian societies engrossed in narcissistic "nationalisms," seems impatient with the unsparing, and potentially transformative, conclusions and prescriptions disinterested analyses of local values, cultural practices, and ways of living provide. This is especially so if contemporary academic politics are traduced, and the indigene is not automatically accorded moral vindication, and when these analyses eclipse authorized narratives - slavery, gender and ethnic oppression, and Carnival - which work in the service of the political status quo. Concretely, in academia, there seems to be no awareness of questions like: How has the internet (via Facebook, Twitter, pornography) affected local social relations? How do homo- and heterosexuality shape public discourse? How does transnational consumerism, transmitted via television and pop music, shape local culture? How are local consumerism, capitalism, and the administration of the state connected? How are culture and political power related? As will be discussed in this paper, some of these studies exist, but are produced outside regional academia, and this deficiency has stunted the region's development potential.

Ironically, there does exist a cultural critique which addresses at least some of these lacunae and aporias in Trinidad. It originates from the preeminent scholar of the Trinidad calypso and Carnival, UWI academic, Gordon Rohlehr. That critique has been essayed in plain sight, and has been ignored by academia, public policy, and the public at large. Apropos, this paper will attempt to do two things: first, to locate Rohlehr in a tradition of Trinidadian (and West Indian) cultural criticism which has existed since the late nineteenth century; and second, examine Rohlehr's critique of Trinidad's nationalist culture and cultural eidos, and identify elements of their production and deployment which pertain to Adorno's idea of the "culture industry," and a few other pertinent ideas (cultural schizophrenia, the devaluation of intellectual work) which, for various reasons, have been avoided by UWI academics. Naturally, this will entail a critical examination of the practice of Cultural Studies at the University of the West Indies.

2. The discipline was "recognized" in the Caribbean Quarterly 51(3\&4) 2005: "Cultural Studies: A New Generation of Scholars." 


\section{TRINIDAD: A BRIEF HISTORY}

Trinidad's social history is distinct from the rest of the Anglo-Caribbean's in several ways. The most obvious is that it consists of roughly equal numbers of citizens of African and Indian descent, a significant mixed-race minority, and small minorities of Europeans, Middle Easterners, and Chinese, which makes it similar in that respect to Rohlehr's native Guyana. However, Trinidad's geography (a small island rather than a continental hinterland), and its relatively recent history - its colonization only began in the late eighteenth century, and immigrants continued to come until well into the twentieth century - make its dynamics unique.

In addition to absorbing immigrants well into the independence era, the island continued to produce significant numbers of emigrants, first in the postwar "wave" to the United Kingdom, and the postcolonial "waves" to the United States and Canada. Between 1950 and 1989, Trinidad's net migration balance was an outflow of more than 280,000 people (Samuel 2005:585). The population was continuously replenished by illegal immigrants from other Caribbean islands - mainly Grenada and St. Vincent, a migratory stream that has persisted from the nineteenth century. Apart from the high "churn rate" in population and the inability of a single ontological, nationalist, religious, or secular-cultural matrix to solidify, other differences were and remain more significant.

The country's language, until the mid-nineteenth century, was French, and its institutions were steeped in French culture, while its laws were Spanish. It entered its plantation phase late, and slavery lasted less than a half-century. By emancipation, there was an unusually low proportion of formerly enslaved, and a high proportion of free mixed-race persons, who were concerned with their own status and autonomy, as distinct from the formerly enslaved, and which has persisted to the present under the guise of "nationalist" rhetoric (Brereton 1993:34). By the end of the nineteenth century, a ruthless program of socially engineered institutional change saw the installation and dominance of British institutional practice and culture, and a sublimation of the English-French conflict into social factions (Brereton 1993:37).

The incoming Indian indentured immigrants (between 1845 and 1917) spoke several Indian languages, and drove the multifarious African (mixedrace, middle-class, and formerly enslaved underclass) groups into an almost involuntary unification, to focus resistance on what they saw as a threat to their claim to the colony. The Indians brought their culture with them, and the Africans benefited from the influx of some 60,000 West African immigrants between 1841 and 1861, whose culture over-wrote the extant post-slavery African retentions, and formed a cultural bulwark for the Afro-descended population (Trotman 2007:211-34, Wood 1968). 
The oppositional cultures, embryonic institutions (educational, cultural, and political) and the relatively undeveloped society led to continuous social frissons: there was no school, language, church, or public sphere where all groups could communicate and be socialized into a common set of values. Because the planters and merchants required the Indo workforce to remain on, or close to the plantations, they were not encouraged to migrate internally, and indeed, their highly visible retained culture became a useful device for emphasizing their difference from the rest of the population.

Democracy and the franchise also came late. Until 1925, a single individual, the governor, held a monopoly of political power, which caused great resentment in the growing numbers of politically conscious, educated black, mixed-race (and later, Indian) middle-class professionals. A limited franchise was granted in 1925, and universal franchise in 1946. The interwar years saw the emergence of Afro- and Indo-nationalist groups, along with a strong Labor Socialist movement, and the emergence of several political factions. The opposing Afro- and Indo-majority cultural factions coalesced around their own ideas of nationalism, but the superiority of British culture remained unquestioned. This conflict-ridden relationship persisted through Independence, with the Afro-nationalist position triumphing electorally in 1956, under the charismatic leadership of the Oxford-educated Eric Williams, and remaining entrenched until 1986 (Meighoo 2002, Oxaal 1982, Ryan 1972). This long season of institutional control allowed the Peoples National Movement (PNM) to entrench its "Creole" worldview as "national" and anything else as "racist and unpatriotic" - with the discourse linked to the retention of political power (Yelvington 1993:13).

The centerpiece of postemancipation Creole culture was the Trinidad Carnival. Its positioning in the urban sphere, and its unapologetically Afrocentric orientation made it a perfect vehicle for promoting Afronationalism, and its political structure (the PNM), under the guise of "national culture," to the exclusion of IndoTrinidad (Van Koningsbruggen 1997, Stuempfle 1995, Yelvington 1993).

Indeed, because of the PNM's cultural manipulation, the single defining aspect of Trinidadian culture is that Carnival, political power, and racial competition have become inextricably intertwined, with the invocation of any one activating the other two. This strategy continued well into the 1990s: the Indo-based political party, the United National Congress's (UNC) accession to political power created a trauma in the Afro section of the population (Ryan 2002:6) which led to open racial conflict, though not physical violence, but via talk radio, the media, and via the medium of Carnival (Ramcharitar 2005:19-78). Naturally, any critique of Carnival pointing out its obvious political deployment and orientation, was discouraged - this was true in academia, as well as in the public sphere (Van Koningsbruggen 1997). 
The UNC was displaced from power in 2001, and the PNM returned from 2002 to 2010. This period saw an intensification of the discourses of ethnic nationalism, the state's, academia's, and Carnival's three-way embrace become cemented in a mythos of multiethnic Trinidad nationalism (Sadre-Orafai 2004:226-27). With the return of the UNC to political power in 2010, the idea that Carnival was the national culture of Trinidad was cemented in orthodoxy, and that government embraced it as the centerpiece of its new multiculturalism policy - without any assessment of whether this was borne out by the facts.

\section{GORDON ROHLEHR AND TRINIDAD}

Into this contentious, racially charged environment, Gordon Rohlehr landed as an insider-outsider, with two assets: his education and formation at a particular historical moment in the region's history, and his understanding of the dynamics of the Afro-Indo political dyad. He was born in Guyana in 1942, attended Queen's College in Georgetown, and was a scholarship undergraduate at the University College of the West Indies (Mona, Jamaica). He was awarded his doctorate from the University of Manchester in 1967, and returned to the University of the West Indies the following year, to Trinidad, where he still lives.

An important aspect of Rohlehr's location in West Indian society and letters resides in his beginnings: his grammar school education made him a privileged colonial. The Queen's Colleges throughout the Anglo-Caribbean were started in the nineteenth century to educate an accomplished stratum of West Indians to occupy positions of importance in the colonial administration. The young men who attended these colleges, according to historian Carl Campbell, were steeped in "English modes of education and thinking" by the inculcation of "English habits and English loyalties." The schools were initially intended for white boys, but well before Rohlehr's time, it was accepted that black and Indian boys would be among the chosen (Campbell 1992:25). He shares this status with V.S. Naipaul, Lloyd Best, Eric Williams, C.L.R. James, Derek Walcott, and many other prominent non-white West Indians who have shaped the destiny of the region. The education was uniform throughout the system so the graduates of the schools were intimately conversant with each other. Doubtless this network was intended to form the basis of an organic society. Though Rohlehr's view, articulated in his essay "Intersecting QRC Lives" (2007:206), is in general agreement, he writes that the purpose of the education system was the production of "an overseer caste." However, at the conference in his honor, at the University of the West Indies, St. Augustine, in late 2007, his classmates from his own Queen's College days in Guyana were visibly, vocally, and proudly in attendance. The links and imprint of that experience were clearly crucial to his formation, as 
it was for Best, James, and Naipaul. However, it seems that the critique of colonialism was enabled by the very education, hence the uniformity of the critique from all these men.

In Trinidad, Rohlehr has made his life's work the detailed examination and analysis of its social history, as refracted through its poets and writers' work, and through Carnival and calypso, using literary criticism as an entrée into social criticism. But his work as a scholar is much more variegated. From the 1970s, he has been fully engaged with the society: he spoke widely, was involved in social movements, published more than one hundred essays in a variety of publications, from the mainstream Caribbean Quarterly to the obscure ones, like Tapia and Moko - which were ostensibly seats of revolutionary rhetoric in the 1970s. The compilation of his early essays, published in 1992, in the collections The Shape of that Hurt (TSH) and My Strangled City (MSC), provide a meticulous social history of 1970s and 1980s Trinidad. His opus, Calypso and Society in pre-Independence Trinidad (CS) (1990), was the distillation of two decades of listening to the calypso, writing about it, and establishing the Geertzian "thick" connections and contexts. He thereafter published A Scuffling of Islands (SI) (2005), and Transgression, Transition, Transformation (TTT) (2007), which saw a divergence in theme and subject of inquiry. His literary criticism also yielded significant books in Black Awakening in The Arrivants of Edward Kamau Brathwaite (1981), and Ancestories: Readings of Kamau Brathwaite's Ancestors (2010). He has been involved in producing numerous radio and television programs, and delivered public lectures on West Indian literature, Carnival, and calypso regionally and abroad. He has held visiting professorships at Harvard, Johns Hopkins, Dartmouth, and various other North American universities. If there is one lacuna in his work, it is that he deals with urban, Afrocreole society, and has little to say about the Indo population, but he is incontestably the most important, erudite, and prolific critic of Trinidadian culture in the last quarter of the twentieth century.

Among the recurrent themes of his first three collections are the political manipulation of culture, the abuse of historical narratives and the devaluation of intellectual work, and the psychological distortions of colonialism which haunt Trinidad. Remarkably, given the putative regard in which he and his work are held, the critique has had no apparent effect - no acknowledgement in academia, public policy, or public debate. ${ }^{3}$ Though he remains esteemed as a scholar of the calypso.

Rohlehr's conclusions about power, culture, and nationalism (and their reception by academia and society), are common to his community of scholars. Lloyd Best, V.S. Naipaul, and Derek Walcott, are contemporary points on a line of cultural criticism stretching back to the nineteenth cen-

3. One UWI, St. Augustine academic, Louis Regis, has continued Rohlehr's work in studying the calypso. See Regis 1999. 
tury, produced similar conclusions. But before tracing this genealogy, a look at the status of the discipline in Trinidad (UWI) is required to explain why Rohlehr's critique has been ignored.

\section{INTRODUCING CULTURAL STUDIES}

In introducing the September-December 2005 issue of Caribbean Quarterly which welcomed "a new generation of scholars," then UWI Chancellor Emeritus Rex Nettleford (2005:v) wrote: "I, for one, was amazed that what I had been doing for years in the quest for relevance and for the kind of truth that is rooted in the reality immediately around me, could be subsumed under the new mantra of Cultural Studies" (emphasis added). The activity he describes as having participated in better describes a related but less elaborate antecedent of today's Cultural Studies. The dynamics of that antecedent practice are best described in T.S. Eliot's essay, "Notes Toward a Definition of Culture," as the "baffling problem of 'culture' [that] underlies the relation of every part of the world to every other," and which included "the relation of great to small nations" and "the colonist to the native" (Kermode 1975:294).

The social critique Eliot describes was a fundamentally moral one - of, for example, righteous anger against colonialist, imperialist, class, or racial injustice. It was inextricable from religion, or more specifically, Christianity, which provided currency for its moral economy, and fleshed out its "structures of feeling," in creating emotional-intellectual responses to the issues examined (Williams 2009:35-50). The epistemological matrix, whose terms were defined in Arnold's Culture and Anarchy (2006), held roughly until the end of World War II.

The postwar period saw the emergence of the global consumer economy dominated by the modern multinational corporation integrated into the structure and function of government, cold war politics in the United States and Caribbean, and postcoloniality in Europe's formerly colonized world. It also saw, consequentially, the growth of transnational media, and the fusion of political groups, media, ethnic groups, and multinational business to create narratives in their own service against various "Others." Naturally, more sophisticated theories and analyses emerged - hybrids of anthropology, sociology, linguistics, literary criticism, history, social psychology, and media studies (West 1999:256-71). Among the seminal theorists of the new cultural paradigm were the Frankfurt School and the Birmingham School, which developed from a base of Marxist philosophy and criticism, and despite Nettleford's sanguinity, it is with these that the University of the West Indies, and the region's cultural critics and social scientists have not kept step, in favor of the local cultural preoccupations of Carnival as a celebration, slavery, and various forms of oppression. These preoccupations are visible in the 
table of contents of Nettleford's "new generation" of scholars' essay subjects: on Rastafari, childbirth, Caribbean dance, dancehall, entrepreneurship and crime, slavery, and Creole language. ${ }^{4}$

That his remarks about his surprise at the new discipline's exigencies are literal, and not ironic, is suggested by Nettleford's statement (in 1991) at a conference organized by the New York-based Research Institute for the Study of Man (RISM), that "[b]elief systems, ideologies, attitudes, sensibilities, lifestyles, are now numbered among the variables that must be studied" by Caribbean academics, since there existed an "epistemological fallacy by closed groups laying claim to exclusive branches of knowledge" (Nettleford 1991:16). As Rohlehr remarked at a regional conference in 1988, "[t]he ISER [Institute of Social and Economic and Social Research at Mona] has never recognized culture as part of the business of social research" (TSH 219). Indeed, the RISM appears to have conducted much research in what could be classified as "Cultural Studies" in the region from independence to the 1980s (Comitas 1991:1-6).

This position, of the tendentious distortion of scholarship (of adopting an isolationist view of African history and culture in the New World), was disparaged by Paul Gilroy in his superb The Black Atlantic, as he berated the "ontological essentialist view" propounded by black intellectuals which was "a commentary on the special needs and desires of relatively privileged castes within the black community" (Gilroy 1993:32-33).

The poverty of the scholarly work within the University of the West Indies in this area was reiterated nearly two decades later by Patricia Northover and Michaeline Critchlow who linked the Caribbean's developmental failures to "a failure to provide analyses capable of providing a better grasp of the forces shaping/challenging the dynamic development of the Caribbean's 'Creole' societies." They criticize contemporary approaches as being "deficient in the analysis of the state-society-economy relationship, or more generally, the relationship between modern power and its subjects" (Northover \& Crichlow 2010:136-37).

The deficiency is visible in even a cursory look at contemporary scholarship on relevant phenomena in Trinidad. The pioneering (and so far, only) work on the Internet and its effects on Trinidadian culture was done by British anthropologists Daniel Miller and Don Slater (2000). Miller (1996) also did the only study of the effect of soap operas on Trinidad audiences in the 1980s. Only recently has the University of the West Indies, via its academics, acknowledged the work of Jamaican-born Stuart Hall, one of the towering figures in Cultural Studies for decades, with the publication of Culture, Politics, Race and Disapora: The Thought of Stuart Hall, edited by UWI academic, Brian Meeks (2007).

\section{Caribbean Quarterly 51(3\&4), p. i (Table of Contents).}


In addition to Miller, other foreign academics' significant works include (among others) Jocelyne Guibault's Governing Sound: The Cultural Politics of Trinidad's Carnival Musics (2007), Stephen Stuempfle's The Steelband Movement: The Forging of a National Art in Trinidad and Tobago (1995), Peter van Koningsbruggen's Trinidad Carnival: A Quest for National Identity (1997), Tejaswini Niranjana's Mobilizing India: Women, Music and Migration between India and Trinidad (2006), and Alvin Magid's Urban Nationalism (1988). Harvey Neptune's Caliban and the Yankees: Trinidad and the United States Occupation (2007), was published by a U.S. press, and Neptune is a Trinidadian, but works in the United States.

In the increasingly globalized academic community, there is nothing remarkable in non-Trinidadians/West Indians studying Trinidad's culture. What is remarkable is that the production of the foreign academics is not matched by local academics. In effect the conversation on culture has not kept up with progressive scholarship. Trinidadian scholarly collections that illustrate the continuation of this agenda include: Music, Memory, Resistance: Calypso and the Caribbean Literary Imagination (2007); Globalization, Diaspora, Caribbean Popular Culture (2004); and Culture In Action: The Trinidad Experience (2004). All these books were about Carnival; all were largely celebrative.

Indeed, surveying books, attending conferences, and auditing the content of the University of the West Indies intellectual production and output in the humanities, one is left with the distinct impression that the Cultural Studies agenda is to establish Caribbean culture as being in step with with metropolitan culture, and as "equal to," despite its deficiencies in cadres of academics, higher education institutions, subdisciplinary specializations, and its conscious choice of a very limited range of study. All this is despite the fact that the English-speaking West Indies now produces significant transnational products in popular music, consumes international media, is immured in Internet technologies, and seems to have a considerable sphere of alternative sexualities which is only just beginning to be openly discussed, amidst much resistance from academia, ${ }^{5}$ government, and other institutions. (Thomas Glave's anthology of queer texts, Our Caribbean, was published in 2008.)

The idea of an agenda of manipulating discourse (proposed explicitly by Gilroy) suggests a specific, if not organized grouping. As Gordon Lewis put it, "the transfer of power from the old empires ... thus means little more, in social power terms, than the consolidation of the ruling class hold [and] a

5. There has been no research on academia's homophobia, but this describes my personal experience lecturing to postgraduate students at the University of the West Indies, St. Augustine, who are influenced and hand-picked by lecturers who are born-again Christians, and openly contemptuous of homosexuality. And, of course, Jamaica's homophobia is well established in regional lore by entertainers like Buju Banton. See Donna Chambers 2008:94-114. 
nascent middle class using independence as a ladder to government, civil service and diplomatic appointments" (emphasis added). For the West Indian population the change "means simply a change of masters only" (Lewis 1996:513). The reason is evident but unpleasant: once in power, the regimes consisting of the formerly colonized immediately took steps to ensure their rules for life, and kept the old social rules and values (ethnicity, class, and color) in the new paradigm.

Derek Walcott in his seminal essay "What the Twilight Says" is more explicit in identifying the "new Brown meritocracy" in Trinidad whose agenda was to "politically educate the peasant but to leave him intellectually unsoiled" (Walcott 1998:31). Percy Hintzen and others described it as "the politicization of black identity" which combined with the "Westminster model of parliamentary democracy inherited from Britain" to form "an instrument of regulation for the country's elite" (Hintzen 2003:399).

In short, values and ways of being, thinking, and feeling (i.e., culture) of the populations were manipulated by their own privileged classes, to preserve a political status quo similar to the colonial one. Hence critics not aligned with this movement, and immured in its epistemology, have been looking at the society and coming to the same conclusions for almost a century-and-a-half.

Naturally, a necessary part of the postcolonial power retention strategy was the neutralization of the political-social critique which demonstrated, or revealed, the now entrenched local power groups as immoral and culpable in the heightened disintegration of the former colonies. This neutralization strategy is visible in the responses to the agents who attempted to provide this critique: Lloyd Best and the New World Group, V.S. Naipaul in his novels The Mimic Men and Guerillas and Derek Walcott in poems like "The Spoiler's Return," "The Schooner Flight," and his major essays "What the Twilight Says: An Overture" and "The Muse of History" (Walcott 1992; 1998).

Best was celebrated but ignored by academia and government. Naipaul has been universally reviled as a "racist." And Walcott's life in Trinidad was one of endless frustration which he documented in his work. It is as a member of this group - which exposed the local variant of the "culture industry" and its effects - that Rohlehr has never been located, or studied, until now.

From essays in the collections already identified, I will attempt to extricate the ideas relevant to the "culture industry." They include (to repeat): a) a colonially originated schizophrenia and mental instability as determinants of the discourses and practices of West Indian culture and society; b) the use of history, and epistemology, as weapons and the devaluation of intellectuality linked to the political status quo; and c) the manipulation of material culture and the distortion of folk culture by government and state authorities for political purposes.

Certainly there exists a danger of rewriting Rohlehr's work in the image of my own project, but my reading and writing here do not decontextualize the 
ideas. I merely foreground marginal themes whose repetition constitutes an irresistible invitation to de-center the work from its Carnival-calypso center.

\section{ANTECEDENTS: J.J. THOMAS, C.L.R JAMES, V.S. NAIPAUL}

The nineteenth-century Trinidadian linguist and philologist J.J. Thomas remains most celebrated for Froudacity (1889), his rebuttal of British historian J.A. Froude's unflattering assessment of the late-nineteenth-century colonial West Indies in his book The Bow of Ulysses: The British in the West Indies (1888).

Thomas was a savant, and arguably the first fully formed "organic" Trinidad intellectual and is generally regarded as a proto-nationalist (by Benn 2004) and as an ethnic nationalist (by Smith 2002), but these are misleading conclusions - a product of the postcolonial knowledge economy (which I described earlier) which requires that historical and cultural phenomena should be interpreted according to ethnic and/or "nationalist" themes.

In fact, Thomas (like his intellectual descendants) would be better qualified as an internationalist. Writing about the "Nationality of Negroes" in the Trinidadian New Era newspaper on September 23, 1872, Thomas warned his readers against insularity in formulating ideas of nation and self:

Greece borrowed letters and science from Phoenicia and Egypt; Rome, intellectual culture from Greece, and all the nations of civilized Europe are debtors to Rome on similar grounds. That we should rebel against this law of international borrowing would be a manifestation of self-sufficiency as unprecedented as it would be fatal.

Thomas's racial views were equally ahead of their time. Though he was conscious of and took pride in his racial origins, in discussing the colony's racial situation in the same newspaper (on September 14, 1874), he reveals "complexional prejudice" within the island's black community:

color prejudice is a ladder with almost numberless rungs. It is a system of social segregation and retaliation. Favoritism, sycophancy, levity and a cravenness too base to be characterized, have made its [sic] highest standpoint a tower of strengths from which its influence on imitative persons, according to the degree to which their blood is diluted, operates in a manner which some deplore, and all can but too well appreciate.

As to the antinomies of these dysfunctions, "Social Contrasts" (published in the New Era between October 4 and November 4, 1875) prescribed "life and civilized citizenship" and the development of the "higher life of 
the community," via books, classical learning, and the European intellectual tradition - echoing Arnoldian values. Thomas identified three traits in Trinidadians which he said worked against the interests of civilized citizenship: "Bambilouism, White-eariness, and Egotism." He wrote: "The moral and social traits of the bambilou may be symbolized by a compounding of the visible qualities of the Chameleon and the Ape." Such a person, he continued, is obsessed with status, and to achieve it copies the traits of others (the British) with "a grotesque earnestness." Such men are "a set of lifelong carnivalists with all the bizarre but none of the intentional ridiculousness of genuine masqueraders." Thomas continues in similar vein expounding white-earism (cowardice) and egotism.

In a later article, in the New Era (June 7, 1880), Thomas provides a glimpse of his life by recounting the experiences he most valued: contemplation of the classics through reading, discussion, and intellectual cultivation. He was also a founder of the Trinidad Athenaeum, a literary society. ${ }^{6}$ (Another important association, which is strangely absent from the published material on Thomas, is that he was a Freemason, inducted into the Lodge Eastern Star in Trinidad, in August 1873. ${ }^{7}$ Doubtless, this contributed to Thomas's views on internationalism, and the idea of knowledge transferred from civilization to civilization. ${ }^{8}$ )

Even from this brief survey, three themes in Thomas's work are apparent: the psychological distortions, including racial neurosis, that colonial cultural exchange produces on native minds; a prescience of the importance of history and epistemology in ordering social life; and recognizing the importance of a broad spectrum of the humanities as a bulwark of civilization.

Thomas's ideas recur through Trinidadian intellectuals' conclusions to the present. Lloyd Brathwaite in his seminal essay, Social Stratification in Trinidad (1953), described the features of the colonial Trinidadian middle class as either "compulsive conformists" or "radicals." These (black and mixed-race middle-class) men were all obsessed with whiteness and lightcolored skin, and possessed traits of cowardice and egotism which caused them to seek power for their own ends, and use it sadistically and primarily for their own satisfaction and vindication (Brathwaite 1953:109-12).

Concerning this recognition of imitation and personality distortion it should be evident that what Thomas and Brathwaite described was later dramatized by their fellow Trinidadian, V.S. Naipaul, in his novel The Mimic

6. Formation of the Athenaeum reported in the Trinidad Chronicle, November 12, 1872, and Thomas's obituary published in the New Era, October 25, 1889.

7. This information was found in membership lists provided by the Grand Lodge of Scotland.

8. This is discussed in some detail in Chapter 4 of my unpublished $\mathrm{PhD}$ thesis (see Ramcharitar 2008a). 
Men. It is remarkable, and emblematic of the central problematic (of evading the potentially discomfiting conclusions that result from cultural analysis) mentioned in the introduction, that there has been no local disinterested examination of Naipaul's formulation, but much ire and personal insult insinuated in its wake. (A theoretical examination was undertaken by Homi Bhabha in his essays "Mimicry and Man" and "Sly Civility" in The Location of Culture [2004]. Walcott's essay "The Caribbean: Culture or Mimicry" [1974], remains the exception.) Conversely, C.L.R. James's Beyond a Boundary is celebrated as one of the great cricket books, but its praise of aspirations to Britishness and its acceptance of colonial status norms, like the high value attached to white- and light-skinnedness, are ignored. Though in his The Case for West Indian Self Government (1933) and Party Politics in the West Indies (1962) James's critique of the Philistine "brown" middle class was scathing and congruent with Naipaul's and Thomas's.

The theme of the value of "Eurocentric" knowledge, which was set against an unspecified philistinism and shallowness in Thomas and James, remained an issue post-independence, when it was dichotomized against "folk" knowledge. The conflict has been a running theme in the region's postcolonial academic and political discourse. It is discussed in Derek Walcott's seminal essay, "What the Twilight Says: An Overture," and in "The Muse of History" as well as exhaustively discussed in his creative work. These themes also recur in Lloyd Best's oeuvre, like his major essay "Independent Thought and Caribbean Freedom" (2003) and his journals New World Quarterly, Tapia, and the Trinidad \& Tobago Review.

A good illustration of Best's style and preoccupations can be found in a newspaper column headlined "Laventille Man," published in the Trinidad Express on November 8, 1994. He wrote, on the problems facing the region, with reference to the education system:

Might it not be significant that the accent is so heavy on rigor and discipline and so light on the romance and enchantment that learning also entails? ... In the most astonishing places we find a resignation to - if not quite a contentment with - the terrors and traumas of materialist society ... The post-independence theme has been enduring paralysis, stasis, at least, a crisis of non-implementation and institutional atrophy. The emerging option is authoritarian command, slavery in a different guise - or anarchy.

The themes of the seemingly endless failure of authoritarianism without its antinomy of Romanticism, and the distortions this leads to - a resignation to terror and trauma - echo, more subtly, those raised by Thomas, Walcott, James. Naipaul and others similarly oriented by their Arnoldian education and socio-historical location. And it is here that Rohlehr is most at home, sustaining and extending this critical position. 


\section{ROHLER'S CONTRIBUTION: \\ PSYCHOLOGY, EPISTEMOLOGY, AND ANTI-INTELLECTUALISM}

Rohlehr's early essays are a blend of cultural archaeology and literary criticism - making links between social sensibility through poems and individuals like Derek Walcott, Wayne Brown, and Eric Roach ${ }^{9}$ and networks of forgotten publications, literary circles, and social movements like Pivot, Embryo, and Kairi, which transmitted the social-cultural discourse of the 1970s and 1980s.

In his "History as Absurdity" a literary evaluation of Eric Williams's From Columbus to Castro, he examines the use of history as a weapon, and provides a psychological profile based on Eric Williams's narcissistic obsession with using it for revenge: "Dr Williams ... still conceives history-writing as the gathering together of a stockpile of facts to be hurled like brickbats against the dead and living imperialists" (MSC 21). The essay also reads like a Fanonian case study, as he details "the daydream the colonial always has, of humiliating massa" in Williams's work, and comments upon the colonial's "blend of love, hatred and contempt for both black and white" (MSC 26). He also links Williams's psychosis to Naipaul's in the desire for power, revenge, and fulfillment in the bosom of the colonizer.

The themes of psychological distortion, and specifically of schizophrenia, recur in many forms, involving literary analysis, individual personalities, and mass behavior. Literarily, the term was used in describing Walcott's and other poets' racial division, being torn between styles and drawn to black and white antecedents (MSC 58), and his embrace of the stereotype of the "tragic mulatto" (MSC 148). In "Man Talking to Man," Rohlehr notes in the 1970 s, even the calypsonians, staunch black nationalists, and PNM loyalists, could no longer reconcile the dissonances between rhetoric and reality, and began to conclude that "madness" was the explanation for the "bewildering paradoxes of civic life." As the decade progressed, "[r]eflections on the rumored madness of the leader eventually became contemplation of the literal madness visible on the streets" [emphasis added]. This created a broken, dispirited citizen which led to the general breakdown of trust, sentience, and eventually, by 1990, of society (MSC 331, 335).

Psychosocial distortion had also afflicted the masses, via colonial discursive strategies from the first decades of the twentieth century: "Propaganda against

9. Eric Roach was a talented and undervalued Tobagonian poet, admired by Derek Walcott and Kamau Brathwaite during his lifetime, but who never met with success or recognition, and took his own life in 1974 . His value has only recently begun to be recognized and celebrated. Peepal Tree Press has published a collection titled The Flowering Rock: Collected Poems 1938-1974 (1992), and Laurence Breiner's study, Black Yeats: Eric Roach and the Politics of Caribbean Poetry (2008). Brown would later win the Commonwealth Prize for Poetry with his collection On the Coast (1974). 
non-European styles and customs had permeated the society at every level, so the keepers of the tradition themselves were ambivalent about its deeper aspects." Thus "the grassroots absorbed and disseminated comic caricatures of their own image which they had derived from the country's ruling elite." The revival and recovery of this knowledge decades later was infused with a pervasive ambiguity, and ambivalence, as to what was folk and what was fake, which was exploited by the postnationalist bourgeoisie (TSH 170-72).

A later essay, "Drums and Minuet: Music, Masquerade and the Mulatto of Style" returns to literary schizophrenia from another vantage - the cultural politics of aesthetic choice among a few writers, and musicians, with regard to their being of mixed race. Rohlehr examines Derek Walcott, Philip Pilgrim, Arthur Seymour, Lorna Goodison, Edgar Mittelholzer, Dennis Scott, and Victor Questel (TTT 82-111).

The theme of colonial distortion in the essays from the 1970s and 1980s materializes in two other motifs: intellectual impotence leading to apocalypse, the culmination of the mental and social distortion. "Man Talking to Man" mentions in passing that by 1966 , there had occurred, via calypso, the "equating of intellectuality with impotence." This was instigated, he implies, by Williams's attacks on the University of the West Indies and indigenous intellectual pursuits. He reported on the University of the West Indies of the early 1970s that:

Lecturers have been expelled for alleged subversive activity and in the Trinidad of 1970, University personnel have been detained on the most fantastic charges and released because Dr Williams himself, now in his guise of Minister of National Security could discover no adequate grounds upon which to hold them (MSC 45).

In "My Strangled City" which examines the art, society, and some personalities and issues which shaped the decade 1964-75, he would mention in passing the continued assault on "[s]mall, impotent groups of guilt-ridden intellectuals throughout the region who display a certain amount of political consciousness" (MSC 214). The center of this dysfunction, he writes (summarizing the assessments of various poets), was/is the University of the West Indies, Mona, campus of the 1950s and 1960s, where the inheritors of the colonial power structure created "a narcissistic prison, a generator of fixed formulae and stereotyped vision” (TSH 219).

Two tragic figures of the 1970s embody the destructive mental effects of postcolonial distortion: critic/poets Victor Questel and Eric Roach. They recur in the essays of the period, and are the subjects of individual essays: "Three for V" and "A Carrion Time," critical elegies to these figures' lives, work, and deaths. Rohlehr's summation (in "Afterthoughts") of the artist's fate in such an environment was dark indeed: "if a finer spirit emerges from 
the carrion of our present, it will be won at the expense of individual defeat, sacrifice, tiredness of the spirit and sickness unto death" (MSC 134).

The larger consequences of this psychological distortion come in the flowering of apocalypse, the 1990 coup, when an Islamist terrorist organization stormed the Parliament and murdered, or caused the murders, of one parliamentarian, dozens of civilians, instigated the destruction of billions of dollars worth of property, and the traumatization of thousands of people.

Rohlehr's examination of the calypsonians' response to 1990 is tinged with asperity at the consequences of a society which held intellectuals in contempt, and which remained emotionally and epistemologically distorted by colonialism. The calypsonians saw "little reason they should present balanced or factually accurate accounts of social and political experience" and "assumed a right to a one-sided monopoly of discourse every bit as authoritarian as the power structure [they] attack" (TSH 335). In this milieu, university lecturers and calypsonians agreed that $\mathrm{Abu}$ Bakr, the leader of the criminals, was a hero, and the society had become one whose "social and cultural mechanisms are all attuned to the task of evading moral responsibility and side-stepping moral commitment" (TSH 345).

This summation - the impotence and devaluation of things intellectual and intellectuals, psychological distortion, and social disintegration - leads to the question: in the absence of the intellectuals, intellectual material, and epistemological guideposts, what was filling the discursive void and programming these social phenomena? The answer is the Trinidad Culture Industry.

\section{THE TRINIDAD CULTURE INDUSTRY}

In "West Indian Poetry: Some Problems of Assessment," Rohlehr notes that post-1970 Trinidad saw a burgeoning youth movement engaged in a critical examination of their cultural antecedents, aimed at political change, which resulted in the "arrests, detentions, shootings and tribunals" of and for its leaders (MSC 127). The youth were encouraged by a pivotal American film, Woodstock (based on the hippie festival) which encouraged escapism through drugs and other diversions of the era. Following on this, Rohlehr observed, "all sorts of people have encouraged Woodstock-type gatherings in Trinidad, from businessmen who were planning a sit-in at Wallerfield in 1970 to the ruling Peoples National Movement" and "attempts to control folk consciousness by sponsorship" which all amounted to a "sickening political gimmickry which ... seeks to control every response of youth" (MSC 127). In "Afterthoughts," he writes that this state-strategy could become "tragic when folk art begins to be used as a tourist attraction or to gain a few more votes" (MSC 134). And yet later, in an interview ("The Space Between Negations"), he would conclude that "the Best Village" (a folk festival sponsored by the 
government) "provides temporary exhibitionist visibility and functions as a palliative against government indifference. Best Village is thus no more than a political circus" (TSH 124).

In "My Strangled City" Rohlehr elaborates further how folk culture was used politically: the local revolutionary intentions of the Black Power Revolution of the 1970s were transmuted into an adjunct of Afro-American "Soul Culture," and "for the rest of the 1970s these [soul] sessions were encouraged by the establishment as a means of channeling dissent and by 1971, various aspects of folk, urban and youth culture were employed as gimmicks" (MSC 178).

Some of these gimmicks were more elaborate than others. Censorship and oppression could, if necessary, escalate to murder. In "The Shape of that Hurt" describing the means by which the state suppressed voices of change, like Walter Rodney's, Rohlehr notes that: "The state could not foster such voices. Where necessary it imprisoned or muzzled them and under extreme circumstances, assassinated the voice. What the State did with great efficiency was to promote Carnivals and festivals throughout the region" (TSH 174).

In "Literature and the Folk" he elaborates on the use of the appropriated calypso (and folk culture generally) in the independence cultural regime: calypsonians "provided a sounding board by which all 'intruders' on the urban scene were placed," and the calypsonians' role in calling Indo citizenship into question (MSC 61-64). He develops the theme in "Man Talking to Man" noting that anticolonialist calypsonians became statist cheerleaders who "legitimized the party and defended it against incipient dissent by opposition forces" (MSC 326). He also, in this remarkable essay, begins to treat the calypso as a mass medium, and examine the construction of image and propagation of values via the medium - a move which, apparently, none of his contemporaries noticed, since there has been no follow-up to this idea. ${ }^{10}$

Clearly Rohlehr saw that Carnival and the folk were being proposed as means of control and substitutes for intellectual endeavor which could precipitate political change. By 1990, in retrospect, he labeled this period as one which saw the emergence of what he labeled "grassroots hucksterism" which derived from the cultural energies of Black Power being fused with the ethnic exigencies of the PNM, to result in the "rage which always seems to be smoldering in the breasts of the dispossessed [not being] released against the old PNM," and the "children of the Black Power era whose loyalty was given not to Geddes Granger/Makandal Daaga of the NJAC but the PNM" (TSH 308).

In "The Culture of Williams: Context, Legacy, Performance," Rohlehr was able to refine and distil all these themes into a causative algorithm: "the active measures adopted by the five successive governments over which $\mathrm{Dr}$

10. Rohlehr acknowledges Frank Manning's essay on calypso as a medium of communication in Serlin \& Soderlund 1991. My own study of the Trinidadian media (Ramcharitar 2005 ) is the only work I know of which has acknowledged this essay. 
Williams presided, to translate watchwords and national slogans into lived cultural reality" (emphasis added). This essay recapitulates the history of post-independence detailing how PNM policy helped create "a nation of animated puppets in what some have portrayed as a danse macabre and others as a theatre of the post-colonial Absurd" (SI 102-3).

It should be clear from this that Rohlehr on the one hand celebrates and documents the value of the folk, its development, and practitioners. On the other, he recognizes its vulnerabilities and its "capture" by the state. The question is not why has this counterdiscourse not been recognized in Rohlehr's work; this has already been answered. The question is what the consequences of this lack of an overarching academic discourse - which would have recognized, discussed, and documented this long before now - have been.

\section{COUNTERCULTURAL STUDIES}

Raymond Williams's remarkable work, Culture and Society: 1780-1950 (1983), proposed that British culture was shaped by a series of discourses, texts and ideas contained and transmitted in books, architecture, newspapers, and works of literature and visual art. For each historical period, he examined the main ideas of the period and how they interacted dialectically with critiques and opposing ideas, and new positions emerged.

Of importance here is that large ideas were constantly challenged, dissembled, and replaced or modified to suit new exigencies. In describing the similarity in the prognosis of the problems and their causes between J.J. Thomas and Gordon Rohlehr and a series of great minds in between, it seems that the fundamental power relationships of small elites manipulating oppressed masses has not changed. The question thus arises: does this mean that there has been no fundamental change in the ideas that have guided and shaped Trinidad?

The obvious answer would be, "Yes." The reasons for this are not difficult to extricate. Why the power relationship has not changed has already been dealt with by Fanon, Brathwaite, and Naipaul: the psychic and psychological damage wrought by colonialism have not yet been exorcised, through the obsessive reliving of the colonialist psychic drama by ruling elites who have held power since Independence. They have, by force, institutional manipulation, and academic suppression, orchestrated a Foucauldian suppression of knowledge (as the academics deride Foucault and other European thinkers like Derrida and Deleuze and Guattari as "irrelevant"), ${ }^{11}$ in effect keeping the

11. These thinkers are not randomly selected: Deleuze and Guattari are important for their effect on Caribbean theorists like Édouard Glissant and Antonio Benítez-Rojo, Foucault was extensively cited by Northover \& Critchlow, cited herein, and his ideas of "suppressed knowledges" and power relations between marginal and central groups are indispensable to Caribbean historiography, as is Derrida's famous textual strategy of deconstruction. 
questions about artistic issues, political issues, and social problems the same and not acknowledging changing realities.

The eternal questions seem to be about race, oppression, folk-nationalism, and commerce - because the answers are standardized by the state, and lead to a nihilistic tribalism which preserves the socioeconomic status quo. A UWI academic, Susan Burke, speaking at a Carnival, multiculturalism, and tourism forum at the University of the West Indies in February 2011, said:

\begin{abstract}
Carnival can be used as a vista through which we can reflect, reformulate or reset our approaches towards the arts and cultural industries in general ... the Carnival gives some insight into the country in general and the cultural industries in particular ... Carnival as a magical mirror. Carnival shows us who we are as a society. 12
\end{abstract}

There could be no clearer vindication of Rohlehr's fears articulated in 1970, about the folk becoming immured in, and seeing as its purpose, the state's tourism agenda - devaluing education and deriding intellectualism, and dogmatizing history and art as vehicles for ethnic and "nationalistic" vindication.

To be sure, there were developments and digressions in Rohlehr's oeuvre: his post-1990 essays, mainly contained in A Scuffling of Islands, look at calypso's reinvention of itself, and the emergence of calypsonians as political and moral critics, and even prophets. And, as already stated, from Rohlehr's last collection (TTT), it seems that his perspective has shifted into themes of personal, rather than larger social significance.

\title{
CONCLUSION
}

The network of ideas relevant to the study of culture, repeated in Rohlehr's essays from 1970-2004, have not been adequately (if at all) engaged by regional academia, past or present. This is because of the University of the West Indies' late "discovery" of cultural studies, its inadequate grasp of the discipline, and its evasion of the devastating critique its application to West Indian reality precipitates, since this critique indicts the classes or cliques to which the academics belong. The cost of this failure is the lack of viable public policy alternatives, and an impoverishment of social discourse.

This means that the region is not producing knowledge to assist in its self-understanding. This mirrors the independence and post-independence situations, where much of the empirical data (statistical, survey, ethnographic, and participant observation) which formed the intellectual independence

12. The presentation can be viewed in its entirety at $h t t p: / / w w w . y o u t u b e . c o m / w a t c h ? v=$ n8KDe8KEtdc. 
discourse in Trinidad was mined and refined by non-Trinidadians including (not exhaustively) Vera Rubin and the RISM, Ivar Oxaal, Morton Klass, Yogendra Malik, Arthur and Juanita Niehoff, and Gordon Lewis. Certainly there are exceptions: Selwyn Ryan's books and edited collections also recognize the need to untangle the knotty social relations that constitute a complex society. These include Race and Nationalism in Trinidad (1972), Social Stratification In Trinidad \& Tobago: Revisited (1991), Deadlock (2002), and his edited collections on the 1990 coup, the 1970 Black Power movement, and the independence experience. Ramesh Deosaran has attempted to provide data on pressing social issues like crime and poverty. Deosaran's study of the 1990 coup, A Society Under Siege: A Study of Political Confusion and Legal Mysticism (1993), and his edited collection, Crime, Delinquency and Justice: A Caribbean Reader (2007) are also commendable attempts (though of uneven quality) to extricate meaning from tortured experience.

At the University of the West Indies, Cultural Studies in practice is indistinguishable from cultural/political populism. This is visible in academics who say openly and without a trace of irony that calypsonians ought to be given the status of social scientists; ${ }^{13}$ a senior citizen who dons an ethnic costume and acquires from the national museum, which apparently does little else, the title of "master artist" and is feted with a month of celebration sponsored by state, university, and international agencies; ${ }^{14}$ in academic and cultural agencies claiming to represent to the whole of "Caribbean culture" organized and run by members of small class-located elites, who nakedly foreground their own, and their accomplices' interests and networks, and receive massive funding from state and international agencies; ${ }^{15}$ and writers noted for their "resistance" to all and sundry oppressive forces and discourses being on the state's payroll ${ }^{16}$ - all this without a dissenting word, or even a recognition of the enormity.

13. Hollis Liverpool (aka calypsonian "Chalkdust"), director of the University of Trinidad and Tobago's Academy of Arts, Letters, Culture and Public Affairs made these statements at a lecture at the Trinidad National Library on July 3, 2008. It was reported in the Trinidad Newsday on July 13, 2008, Section A, p. 19 in an article by Kevin Baldeosingh. Liverpool made the same argument, less directly, in Pouchet-Paquet 2007. 14. Leroy Clarke, a Trinidadian painter, and the country's most high-profile Afrocentrist (he dresses in African garb, he acquired the title of African Chief, and is regularly seen in public via newspaper and television stories) in 2008 proclaimed himself a "Master" and was feted for a month by the Central Bank of Trinidad \& Tobago, the Trinidad \& Tobago Commission for UNESCO, the National Library, and UWI academics. Advertisements were taken out in the press to announce events with these institutions' imprimaturs. For example: Trinidad Guardian, November 16, 2008, Section A, p. 37.

15. This refers to the now-defunct CCA7 in Trinidad, described in Ramcharitar 2008b. 16. Earl Lovelace was the artistic director of Carifesta IX. This is not documented on Carifesta's website, but is mentioned in an interview with Caribbean Beat magazine: http:// www.meppublishers.com/online/caribbean-beat/archive/index.php?pid=6001\&id=cb81-154. 
Gordon Rohlehr's accomplishments in mapping this territory are monumental. But monuments can crumble if left untended, isolated, and forgotten. As Paul Gilroy (1993:33-34) put it: "Is this impulse towards cultural protectionism the most cruel trick which the west can play upon its dissident affiliates?"

\section{REFERENCES}

AdORNO, THEODOR W., 1991. The Culture Industry: Selected Essays on Mass Culture. London: Routledge.

—, \& MAX HORKHEIMER, 1999. The Culture Industry: Enlightenment as Mass Deception. In Simon During (ed.), The Cultural Studies Reader. London: Routledge, pp. 31-41.

ARnold, MATTHEW, 2006. Culture and Anarchy. Oxford: Clarendon Press. [Orig. 1869.]

BENN, DENIS, 2004. The Caribbean: An Intellectual History, 1774-2003. Kingston: Ian Randle Publishers.

BeST, LLOYD, 2003. Independent Thought and Caribbean Freedom. In Selwyn Ryan (ed.), Independent Thought and Caribbean Freedom: Essays in Honour of Lloyd Best. St. Augustine, Trinidad: UWI Sir Arthur Lewis Institute of Social and Economic Studies, pp. $1-34$.

BHABHA, HOMI, 2004. The Location of Culture. London: Routledge.

Brathwaite, L.E., 1975. Social Stratification in Trinidad: A Preliminary Analysis. Mona, Jamaica: Institute of Social and Economic Research. [Orig. 1953.]

Brereton, Bridget, 1993. Social Organisation and Class, Racial and Cultural Conflict in Nineteenth-Century Trinidad and Tobago. In Kevin Yelvington (ed.), Trinidad Ethnicity. London: Macmillan, pp. 33-55.

CAMPBELl, CARL C., 1992. Colony and Nation: A Short History of Education in Trinidad and Tobago, 1834-1986. Kingston: Ian Randle.

CHAMBERS, DONNA, 2008. A Postcolonial Interrogation of Attitudes toward Homosexuality and Gay Tourism: The Case of Jamaica. In Marcella Daye, Donna Chambers \& Sherma Roberts (eds.), New Perspectives in Caribbean Tourism. London: Routledge, pp. 94-114.

COMITAS, LAMBros, 1991. RISM and Caribbean Social Science. In Errol Miller (ed.), Education and Society in the Commonwealth Caribbean. Kingston: UWI Institute of Social and Economic Research, pp. 1-6.

DAYE, MARCELla, DONNA CHAMBERS \& SHERMA RoBERTS (eds.), 2008. A Postcolonial Interrogation of Attitudes toward Homosexuality and Gay Tourism: The Case of Jamaica. New Perspectives in Caribbean Tourism, pp. 94-114. 
Deosaran, Ramesh, 1993. A Society Under Seige: A Study of Political Confusion and Legal Mysticism. St. Augustine, Trinidad: McAL Psychological Research Centre.

— (ed.), 2007. Crime, Delinquency and Justice: A Caribbean Reader. Kingston: Ian Randle.

Froude, JAmES AnTHONy, 2010. The English in the West Indies: Or the Bow of Ulysses. Cambridge: Cambridge University Press. [Orig. 1888.]

GILroy, Paul, 1993. The Black Atlantic: Modernity and Double Consciousness. Cambridge MA: Harvard University Press.

Glave, Thomas (ed.), 2008. Our Caribbean: A Gathering of Gay and Lesbian Writing from the Antilles. Durham NC: Duke University Press.

Guibault, Jocelyne, 2007. Governing Sound: The Cultural Politics of Trinidad's Carnival Musics. Chicago: University of Chicago Press.

Hintzen, Percy C., 2003. Rethinking Democracy in the Post-Nationalist State: The Case of Trinidad and Tobago. In Holger Henke \& Fred Reno (eds.), Modern Political Culture in the Caribbean. Kingston: UWI Press, pp. 395-423.

JAMES, C.L.R., 1933. The Case for West Indian Self Government. London: Hogarth Press.

—, 1961. Party Politics in the West Indies. San Juan, Trinidad: Vedic Enterprises.

_, 1993. Beyond a Boundary. Durham NC: Duke University Press. [Orig. 1963.]

Kermode, FranK (ed.), 1975. Selected Prose of T.S. Eliot. New York: Harcourt Brace/ Farrar Straus \& Giroux.

KoningsbrugGen, PeTER VAn, 1997. Trinidad Carnival: A Quest for National Identity. London: Macmillan.

LEWIS, GORDON, 1996. The Challenge of Independence in the British Caribbean. In Hilary Beckles \& Verene Shepherd (eds.), Caribbean Freedom: Economy and Society from Emancipation to the Present. London / New Jersey / Kingston: Marcus Wiener/James Currey/Ian Randle, pp. 511-18.

Magid, Alvin, 1988. Urban Nationalism: A Study of Political Development in Trinidad. Gainesville: Combined University Presses of Florida.

MEEKS, BRIAN, (ed.), 2007. Culture, Politics, Race and Diaspora: The Thought of Stuart Hall. Kingston: Ian Randle.

MeIGHOO, KIRK, 2003. Politics in a Half Made Society: Trinidad and Tobago 1925-2001. Kingston: Ian Randle.

MILLER, DANIEL, 1996. The Young and the Restless in Trinidad: A Case of the Local and Global in Mass Consumption. In Paul Marris \& Sue Thornham (eds.), Media Studies: A Reader. Edinburgh: University of Edinburgh Press, pp. 503-16.

MiLler, DANIEL \& DON SLATER, 2000. The Internet: An Ethnographic Approach. London: Berg Publishing.

NAIPAUL, V.S., 1969. The Mimic Men. London: Picador 
—, 1990. Guerillas. New York: Ballantine Books

NeTtLeFORD, REX, 1991. Education and Society in the Commonwealth Caribbean, Issues and Problems. In Errol Miller (ed.), Education and Society in the Commonwealth Caribbean. Kingston: Institute of Social and Economic Research, pp. 15-25.

—, 2005. Introduction. Caribbean Quarterly 51(3\&4):v-x.

NIRANJANA, TEJASWINI, 2006. Mobilizing India: Women, Music and Migration between India and Trinidad. Durham NC: Duke University Press.

Neptune, Harvey, 2007. Caliban and the Yankees: Trinidad and the United States Occupation. Chapel Hill: University of North Carolina Press.

Northover, PATRICIA \& Michaeline CRitChlow, 2010. Size, Survival, and Beyond: A Critical Underlabouring for "Fleeing the Plantation." In Brian Meeks \& Norman Girvan (eds.), The Thought of the New World: The Quest for Decolonization. Kingston: Ian Randle, pp. 136-71.

OXAAL, IVAR, 1982. Black Intellectuals Come to Power: The Rise of Creole Nationalism in Trinidad and Tobago. Boston: Schenkman Publishing.

RAMCHARITAR, RAYMOND, 2005. Breaking the News: Media and Culture in Trinidad. San Juan, Trinidad: Lexicon Trinidad.

—, 2008a. The Hidden History of Trinidad: Underground Culture in Trinidad 1870-1970, $\mathrm{PhD}$ Thesis, University of the West Indies, St. Augustine, Trinidad.

-, 2008b. Tourist Nationalism in Trinidad and Tobago. In Marcella Daye, Donna Chambers \& Sherma Roberts (eds.), New Perspectives in Caribbean Tourism. New York: Routledge, pp. 79-94.

ROHLEHR, GORDON, 1981. Pathfinder: Black Awakening in The Arrivants of Edward Kamau Brathwaite. Tunapuna, Trinidad: G. Rohlehr.

—, 1992a. My Strangled City and Other Essays. Port of Spain: Longman.

—, 1992b. The Shape of that Hurt and Other Essays. Port of Spain: Longman.

—, 2004. A Scuffling of Islands: Essays on Calypso. San Juan, Trinidad: Lexicon Trinidad.

-, 2007. Transgression, Transition, Transformation: Essays in Caribbean Culture. San Juan, Trinidad: Lexicon Trinidad.

—, 2010. Ancestories: Readings of Kamau Brathwaite's Ancestors. San Juan, Trinidad: Lexicon Trinidad.

RYAN, SELWYN D., 1972. Race and Nationalism in Trinidad and Tobago: A Study of Decolonization in a Multiracial Society. Toronto, Canada: University of Toronto Press.

—, 2002. Deadlock!: Ethnicity and Electoral Competition in Trinidad and Tobago, 1995 2002. St. Augustine, Trinidad and Tobago: Sir Arthur Lewis Institute, Institute Social and Economic Research. 
— (ed.), 1991. Social Stratification in Trinidad and Tobago: Revisited. St. Augustine: Institute of Social and Economic Research.

SADRE ORAFAI, STEPHANIE, 2005. Hypernationalist Discourse in the Rapso Movement in Trinidad \& Tobago. In Keith Nurse \& Christine Ho (eds.), Globalisation, Diaspora, Popular Culture. Kingston: Ian Randle, pp. 215-42.

SAMUEL, Wendell, 2005. Migration and Remittances: A Case Study in the Caribbean. In Dennis Pantin (ed.), The Caribbean Economy: A Reader. Kingston: Ian Randle Publishers, pp. 572-89.

SMITH, FAITH, 2002. Creole Recitations: John Jacob Thomas and Colonial Formation in the Late Nineteenth-Century Caribbean. Charlottesville: University of Virginia Press.

STUEMPFLE, STEPHEN, 1995. The Steelband Movement: The Forging of a National Art in Trinidad and Tobago. Philadelphia: University of Pennsylvania Press.

ThOMAS, JoHn J., 2006. Froudacity: West Indian Fables Explained. Middlesex: Echo Press. [Orig. 1889.]

TROTMAn, DAVID, 2007. Reflections on the Children of Shango: An Essay on a History of Orisha Worship in Trinidad. Slavery \& Abolition: A Journal of Slave and Post-Slave Studies 28(2):211-34.

WALCOTT, DEREK, 1974. The Caribbean: Culture or Mimicry. Journal of Interamerican Studies and World Affairs 16(1):3-13

—, 1992. Collected Poems: 1948-1984. London: Faber Paperbacks.

—, 1998. What the Twilight Says: Essays. London: Faber and Faber.

West, Cornel, 1999. The New Cultural Politics of Difference. In Simon During (ed.), Cultural Studies: A Critical Introduction. London: Routledge, pp. 256-70.

WiLliams, RAYMOND, 1983. Culture and Society: 1780-1950. New York: Columbia University Press. [Orig. 1958.]

—, 2009. On Structures of Feeling. In Jennifer Harding \& Deidre Pribram (eds.), Emotions: A Cultural Studies Reader. New York: Routledge, pp. 35-50.

WoOD, DONALD, 1968. Trinidad in Transition: The Years After Slavery. London: Oxford University Press.

Yelvington, KeVIn, 1993. Introduction. In K. Yelvington (ed.), Trinidad Ethnicity. London: Macmillan, pp. 1-33.

\section{RAYMOND RAMCHARITAR}

Orchard Gardens

Chaguanas

Trinidad, West Indies

<raymondramcharitar@yahoo.com> 